\title{
Agromyces albus sp. nov., isolated from a plant (Androsace sp.)
}

\author{
Lubov V. Dorofeeva, ${ }^{1}$ Valentina I. Krausova, ${ }^{1}$ Lyudmila I. Evtushenko ${ }^{1}$ \\ and James M. Tiedje ${ }^{2}$ \\ ${ }^{1}$ VKM - All-Russian Collection of Microorganisms, G. K. Skryabin Institute of Biochemistry and \\ Physiology of Microorganisms, Russian Academy of Sciences, Pushchino, Moscow Region, \\ 142290, Russia \\ ${ }^{2}$ Center for Microbial Ecology, Michigan State University, East Lansing, MI 48824-1325, USA
}

Correspondence

Lyudmila I. Evtushenko

evtushenko@ibpm.pushchino.ru

\begin{abstract}
Agromyces albus sp. nov. is proposed for an aerobic, oxidase- and catalase-positive actinomycete that was isolated from the above-ground part of a plant (Androsace sp., in the family Primulaceae). The strain is characterized by white colonies, fragmenting hyphae that penetrate into agar media and chemotaxonomic properties that are typical of the genus Agromyces. Analysis of 16S rDNA sequences confirmed that the strain belongs to the genus Agromyces and revealed its close phylogenetic relationship with Agromyces ramosus. DNA-DNA pairing studies showed that the strain belongs to a separate genomic species; this is consistent with its distinction from other Agromyces species at the phenotypic level. The $\mathrm{G}+\mathrm{C}$ content of the DNA was $69 \cdot 0 \mathrm{~mol} \%$. The type strain is VKM Ac- $1800^{\top}\left(=\mathrm{UCM} \mathrm{Ac}-623^{\mathrm{T}}\right)$.
\end{abstract}

The genus Agromyces was established by Gledhill \& Casida (1969) for microaerophilic to aerobic, filamentous, branching, fragmenting, catalase-negative actinomycetes that showed a negative oxidase reaction and inhabited soil; it originally contained a single species, Agromyces ramosus. Later, strictly aerobic, catalase- and oxidase-positive and non-filamentous agromycetes were described (Zgurskaya et al., 1992; Suzuki et al., 1996; Takeuchi et al., 2001; Li et al., 2003). Members of the genus are characterized by B2 $\gamma$-type peptidoglycan [based on L-DAB (2,4-diaminobutyric acid) (Schleifer \& Kandler, 1972)], the major isoprenoid quinone MK-12 and the predominant cellular fatty acids anteiso$\mathrm{C}_{15: 0}$, anteiso- $\mathrm{C}_{17: 0}$ and iso- $\mathrm{C}_{16: 0}$ (Gledhill \& Casida, 1969; Zgurskaya et al., 1992; Suzuki et al., 1996; Sasaki et al., 1998; Takeuchi et al., 2001; Li et al., 2003). Currently, the genus harbours eight species and four subspecies with validly published names, which are presented in Table 1; they were all isolated from soil or the mangrove rhizosphere. In this work, we report the characterization of Agromyces albus sp. nov., which was isolated from the above-ground part of a plant (Androsace sp., in the family Primulaceae) collected at the seed-formation stage in the Central-Chernozem Biosphere Park, Belgorod region, Russia.

For isolation of micro-organisms, the surface-unsterilized part of the plant (stem top with several leaves and inflorescence) was cut into pieces, added to $1 \mathrm{ml} 0 \cdot 85 \% \mathrm{NaCl}$

Abbreviation: L-DAB, 2,4-diaminobutyric acid.

The GenBank/EMBL/DDBJ accession number for the $16 \mathrm{~S}$ rDNA sequence of Agromyces albus VKM Ac- $1800^{\top}$ is AF503917. $(\mathrm{w} / \mathrm{v})$ and ground with a pestle. One drop of this suspension was plated onto modified corynebacterium agar that contained 5 g glucose, 3 g yeast extract, $5 \mathrm{~g}$ casein peptone, $2 \mathrm{~g}$ Casamino acids, $3 \mathrm{~g}$ beef extract, $5 \mathrm{~g} \mathrm{NaCl}, 15 \mathrm{~g}$ agar, $100 \mathrm{ml}$ skimmed milk and $900 \mathrm{ml}$ distilled water $(\mathrm{pH} \mathrm{7 \cdot 2-}$ $7 \cdot 4)$ and incubated for 3 weeks at room temperature $\left(18-24^{\circ} \mathrm{C}\right)$. Morphology and life cycle were studied in cultures grown on corynebacterium (CB) agar (Zgurskaya et al., 1992) by phase-contrast microscopy. Gram-reaction was tested by the rapid test with $\mathrm{KOH}$ (Ryu, 1938). Physiological and chemotaxonomic features were examined as described previously (Evtushenko et al., 2000). For chemotaxonomic study, shaken cultures had been grown in liquid CB medium and harvested at the exponential-growth phase (20-24 h). Methods used for extraction and purification of DNA and $16 \mathrm{~S}$ rDNA amplification and analyses were described by Evtushenko et al. (2000). GenBank, DDBJ and EMBL accession numbers of the sequences of Agromyces species that were used in phylogenetic analysis are shown in Fig. 1. The DNA G $+\mathrm{C}$ content was determined by thermal denaturation and DNA-DNA relatedness was studied by the membrane filter method as reported previously (Evtushenko et al., 2002). ${ }^{3} \mathrm{H}$-labelled DNA was obtained by using deoxy$\left[1^{\prime}, 2^{\prime}, 5^{\prime}-{ }^{3} \mathrm{H}\right] \mathrm{CTP}$ and a Nick Translation kit (N5500; Amersham Biosciences).

Colonies of strain VKM Ac- $1800^{\mathrm{T}}$ on CB agar were visible after $24-36 \mathrm{~h}$ and were white, circular and opaque. Branching substrate hyphae $(0 \cdot 3-0 \cdot 6 \mu \mathrm{m}$ in width) that broke up into diphtheroid and rod-shaped, irregular, nonmotile fragments and penetrated into agar were formed. 
Table 1. Characteristics that differentiate Agromyces albus sp. nov. from other species of the genus Agromyces

Strains: 1, A. albus VKM Ac- $1800^{\mathrm{T}}$; 2, A. aurantiacus YIM $21741^{\mathrm{T}}$; 3, A. bracchium VKM Ac-2088 ${ }^{\mathrm{T}}$; 4, A. cerinus subsp. cerinus VKM Ac-1340 ${ }^{\mathrm{T}}$; 5, A. cerinus subsp. nitratus VKM Ac-

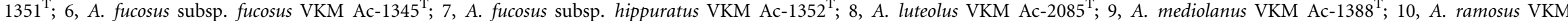
Ac-1198 ${ }^{\mathrm{T}}$; 11, A. rhizospherae VKM Ac-2086 ${ }^{\mathrm{T}}$. Data from Gledhill \& Casida (1969), Zgurskaya et al. (1992), Suzuki et al. (1996), Takeuchi \& Hatano (2001), Li et al. (2003) and this study. Abbreviations: W, white; O, orange; PW, pink-white; PG, pink-grey; Y, yellow; +, positive; -, negative; D, weakly positive or variable among tests; ND, not determined; Fruc, fructose; Fuc, fucose; Gal, galactose; Glu, glucose; Man, mannose; Rha, rhamnose; Rib, ribose; Tyv, tyvelose; Xyl, xylose.

\begin{tabular}{|c|c|c|c|c|c|c|c|c|c|c|c|}
\hline Characteristic & 1 & 2 & 3 & 4 & 5 & 6 & 7 & 8 & 9 & 10 & 11 \\
\hline Colony colour & W & $\mathrm{O}, \mathrm{PW}, \mathrm{PG}, \mathrm{Y}$ & $\mathrm{Y}$ & Y & Y & $\mathrm{Y}$ & Y & $\mathrm{Y}$ & Y & W & $\mathrm{Y}$ \\
\hline Hyphae & + & + & + & + & + & + & + & + & - & + & + \\
\hline Catalase production & + & - & + & + & + & + & + & + & + & - & + \\
\hline Oxidase test & + & ND & + & + & + & + & + & + & + & - & $\mathrm{D}$ \\
\hline Microaerophilic & - & - & - & - & - & - & - & - & - & + & - \\
\hline \multicolumn{12}{|l|}{ Acid from: } \\
\hline D-Arabinose & + & - & - & - & - & + & + & - & - & + & - \\
\hline D-Galactose & + & + & + & + & + & + & + & - & + & - & - \\
\hline D-Glucose & + & - & + & + & + & + & + & + & + & - & + \\
\hline Inulin & + & + & - & - & - & + & - & - & - & + & - \\
\hline Salicin & + & - & + & + & $\mathrm{D}$ & + & - & - & + & - & + \\
\hline D-Sucrose & + & + & + & + & + & + & + & $\mathrm{D}$ & + & + & - \\
\hline \multicolumn{12}{|l|}{ Hydrolysis of: } \\
\hline Casein & + & ND & - & - & - & - & - & - & - & - & - \\
\hline Starch & + & + & + & + & + & + & + & + & - & ND & + \\
\hline Hypoxanthine & + & ND & - & + & + & + & + & - & + & - & - \\
\hline Xanthine & - & ND & - & - & - & - & - & - & + & - & - \\
\hline Growth at $4 \% \mathrm{NaCl}$ & - & ND & + & - & + & - & - & + & + & $\mathrm{D}$ & + \\
\hline $\begin{array}{l}\text { DNA G+C content } \\
(\mathrm{mol} \%)\end{array}$ & $69 \cdot 0$ & $72 \cdot 8$ & $70 \cdot 0$ & $70 \cdot 5$ & $70 \cdot 9$ & $70 \cdot 6$ & $70 \cdot 8$ & $71 \cdot 1$ & $72 \cdot 3$ & $68 \cdot 9$ & $71 \cdot 2$ \\
\hline Cell-wall sugars* & $\begin{array}{l}\text { Rha (Gal, } \\
\text { Glu, Man) }\end{array}$ & $\begin{array}{l}\text { Rha (Gal, } \\
\text { Glu, Man) }\end{array}$ & $\begin{array}{l}\text { Rha (Gal, } \\
\text { Glu, Man) }\end{array}$ & $\begin{array}{l}\text { Gal, Rha, } \\
\text { Tyv (Man) }\end{array}$ & $\begin{array}{l}\text { Gal (Glu, } \\
\text { Man, Rib) }\end{array}$ & $\begin{array}{l}\text { Gal, Rha, Fuc } \\
\text { (Glu, Man) }\end{array}$ & $\begin{array}{l}\text { Gal, Rha } \\
\text { (Man) }\end{array}$ & $\begin{array}{l}\text { Rha, Fruc } \\
\text { (Glu, Man) }\end{array}$ & ND & $\begin{array}{l}\text { Gal, Glu, Man, } \\
\text { Rha, Xyl }\end{array}$ & $\begin{array}{l}\text { Rha } \\
\text { (Glu, Man) }\end{array}$ \\
\hline Menaquinones $\dagger$ & MK-12 (11) & MK-12 & MK-12 (13) & MK-12 (13) & MK-12 (13) & MK-12 (13) & MK-12 (13) & MK-12 (11) & $\begin{array}{l}\text { MK-12 } \\
(11,10)\end{array}$ & MK-12 (13) & MK-12, 11 \\
\hline Source & $\begin{array}{l}\text { Above-ground } \\
\text { part of } \\
\text { Androsace sp. }\end{array}$ & Soil & $\begin{array}{l}\text { Rhizosphere } \\
\text { of Bruguera } \\
\text { gymnorrhiza }\end{array}$ & Soil & Soil & Soil & Soil & $\begin{array}{l}\text { Rhizosphere of } \\
\text { Sonneratia alba }\end{array}$ & Soil & Soil & $\begin{array}{l}\text { Rhizosphere of } \\
\text { Sonneratia alba }\end{array}$ \\
\hline
\end{tabular}

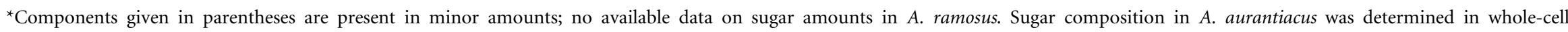
hydrolysates (Li et al., 2003).

$\dagger$ Designation of Collins \& Jones (1981). Menaquinones in parentheses are present as the second most common component. 


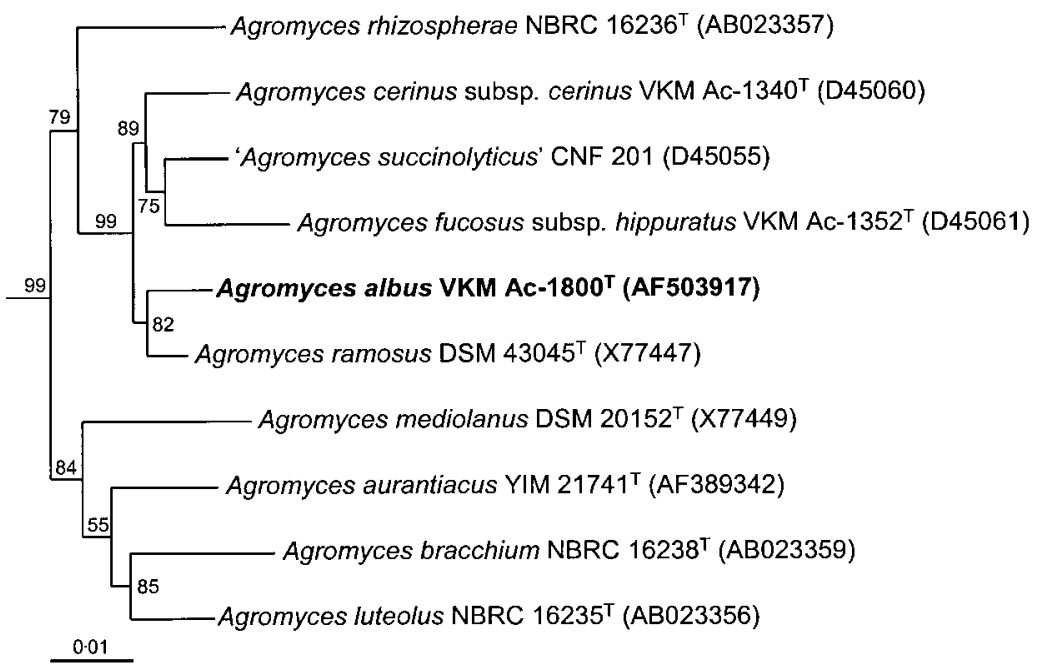

Fig. 1. Phylogenetic tree showing the position of Agromyces albus sp. nov., based on 16S rDNA analysis. Brevibacterium linens DSM $20425^{\top}$ (GenBank no. X77451) served as an outgroup (not shown). Bootstrap values, expressed as a percentage of 500 replications, are shown at branching points. Bar, 1 nucleotide substitution per 100 nucleotides.

Aerial hyphae and spores were not observed. The strain was aerobic, catalase- and oxidase-positive and mesophilic (optimum growth temperature, $26-28^{\circ} \mathrm{C}$ ). It was Grampositive and contained DAB, alanine, glutamic acid and glycine (molar ratio, $1 \cdot 7: 0 \cdot 9: 1 \cdot 0: 1 \cdot 1$ ) and also muramic acid and glucosamine in the peptidoglycan. The amino acid ratio was consistent with peptidoglycan type B $2 \gamma$. Cell-wall sugars included rhamnose as the predominant component and minor amounts of glucose, galactose and mannose. No mycolic acids were present. The major isoprenoid quinone was menaquinone $\mathrm{MK}-12$, although $\mathrm{MK}-11$ occurred in small quantities. The DNA G $+\mathrm{C}$ content was $69 \cdot 0 \mathrm{~mol} \%$. The strain used a wide spectrum of carbon and nitrogen sources for growth and degraded some organic compounds, including casein (see species description).

Phylogenetic analysis of the $16 \mathrm{~S}$ rDNA sequence (1486 bp) of VKM Ac- $1800^{\mathrm{T}}$ revealed that this strain belonged to the Agromyces phylogenetic cluster, formed a tight group with A. ramosus, Agromyces cerinus, Agromyces fucosus and 'Agromyces succinolyticus' with $99 \%$ bootstrap support and was closest to $A$. ramosus (Fig. 1). The binary sequence similarity of our strain to $A$. ramosus was $98 \cdot 8 \%$. Subsequent DNA-DNA hybridization studies revealed $34 \%$ reassociation of VKM Ac- $1800^{\mathrm{T}}$ DNA with its phylogenetic neighbour $A$. ramosus VKM Ac- $1198^{\mathrm{T}}$ and $30-32 \%$ reassociation with $A$. cerinus subsp. cerinus VKM Ac- $1340^{\mathrm{T}}$, A. fucosus subsp. fucosus VKM Ac- $1345^{\mathrm{T}}$ and A. fucosus subsp. hippuratus VKM Ac-1352 ${ }^{\mathrm{T}}$. DNA homology values of our strain with Agromyces rhizospherae VKM Ac- $2086^{\mathrm{T}}$, Agromyces bracchium VKM Ac- $2088^{\mathrm{T}}$ and Agromyces luteolus VKM Ac-2085 ${ }^{\mathrm{T}}$ were 27, 29 and $31 \%$, respectively; Agromyces mediolanus VKM Ac- $1388^{\mathrm{T}}$ has the lowest DNA homology value $(13 \%)$.

The phylogenetic data obtained indicate that strain VKM Ac $-1800^{\mathrm{T}}$ is genomically distinct and represents a separate genomic species (Wayne et al., 1987). This is consistent with its differentiation from other Agromyces species at the phenotypic level (Table 1). The most striking features that distinguish it from all rapidly growing, yellow-pigmented species are the white colour of its colonies and its ability to hydrolyse casein. At the same time, it can be differentiated from the non-pigmented, microaerophilic species $A$. ramosus by rapid growth under aerobic conditions, positive catalase and oxidase tests, a number of other physiological characteristics and the absence of xylose in the cell wall. Thus, on the basis of both molecular genetic and phenotypic findings, we propose that strain VKM Ac- $1800^{\mathrm{T}}$, isolated from Androsace sp., is classifed as a novel species, Agromyces albus sp. nov.

\section{Description of Agromyces albus sp. nov.}

Agromyces albus (al'bus. L. adj. albus white, referring to the white colour of colonies).

Colonies on CB agar are white, circular, somewhat convex, opaque and penetrate into agar media. Forms branching hyphae (width, $0 \cdot 3-0 \cdot 6 \mu \mathrm{m}$ ) that break up into diphtheroid and rod-like, irregular and non-motile fragments. No aerial mycelium or spore formation. Gram-positive. Aerobic; catalase- and oxidase-positive. Mesophilic; growth occurs between 7 and $37^{\circ} \mathrm{C}$ (optimum, 26-28 ${ }^{\circ} \mathrm{C}$ ). Adonitol, Darabinose, cellobiose, D-fructose, D-fucose, D-galactose, Dglucose, glycerol, inositol, inulin, lactose, lyxose, maltose, D-mannitol, D-mannose, melibiose, L-rhamnose, raffinose, salicin, L-sorbose, sucrose, trehalose, turanose and D-xylose are used as carbon sources for growth in salt medium supplemented with $0 \cdot 1 \%(\mathrm{w} / \mathrm{v})$ yeast extract and $0 \cdot 1 \%$ (w/v) casitone. Dextran, dulcitol, melezitose, meso-erythritol, ribose and sorbitol are not used as carbon sources in the same medium. Acids are produced from D-arabinose, D-galactose, D-glucose, inulin, mannose, melibiose, salicin and sucrose. Alkaline reactions are observed with acetate, fumarate, malate and maleinate, but no reaction occurs with citrate, formate, oxalate, propionate, succinate or tartrate. Methyl red test is positive and Voges-Proskauer test is negative. $\mathrm{H}_{2} \mathrm{~S}$ is produced. Casein, hypoxanthine, Tween 40 and starch are decomposed; gelatin, tyrosine, xanthine, Tween 60, Tween 80 and urea are not hydrolysed. Sensitive to $4 \%(\mathrm{w} / \mathrm{v}) \mathrm{NaCl}$. Tolerates the following antibiotics $\left(\mu \mathrm{g} \mathrm{ml}^{-1}\right)$ : amikacin (30), clindamycin (30), lincomycin 
(30), rubomycin (30) and streptomycin (30). Sensitive to ampicillin (10), cefazolin (10), doxycycline (5), erycycline (10), gentamicin (30), karbonicillin (30), levomycetin (10), metacycline (10), oletetrin (10), oxacillin (30) and rifampicin (10). DNA $\mathrm{G}+\mathrm{C}$ content is $69 \cdot 0 \mathrm{~mol} \%$. Predominant cell-wall sugar is rhamnose; minor amounts of glucose, galactose and mannose are present. Major menaquinone is MK-12, with a small amount of MK-11. Cell-wall peptidoglycan amino acids are L-DAB, alanine, glutamic acid and glycine in a molar ratio consistent with peptidoglycan type $\mathrm{B} 2 \gamma$.

The type strain, VKM Ac- $1800^{\mathrm{T}}$, has been deposited in the All-Russian Collection of Microorganisms (VKM) and Ukrainian Collection of Microorganisms (UCM Ac- $623^{\mathrm{T}}$ ). Isolated from a sample of leaves and inflorescence of Androsace sp. in the family Primulaceae.

\section{Acknowledgements}

This work was financially supported by grant no. 00-04-49074 of the Russian Foundation of Basic Research and NSF grants INT 9315089 and DEB 9120006 to the Center for Microbial Ecology. We thank Mr Andrey Tolstykh and the administration of Central-Chernozem Biosphere Park, Belgorod region, for providing plant samples for analysis.

\section{References}

Collins, M. D. \& Jones, D. (1981). Distribution of isoprenoid quinone structural types in bacteria and their taxonomic implications. Microbiol Rev 45, 316-354.

Evtushenko, L. I., Dorofeeva, L. V., Subbotin, S. A., Cole, J. R. \& Tiedje, J. M. (2000). Leifsonia poae gen. nov., sp. nov., isolated from nematode galls on Poa annua, and reclassification of 'Corynebacterium aquaticum' Leifson 1962 as Leifsonia aquatica (ex Leifson 1962) gen. nov., nom. rev., comb. nov. and Clavibacter xyli Davis et al. (1984) with two subspecies as Leifsonia xyli (Davis et al. 1984) gen. nov., comb. nov. Int J Syst Evol Microbiol 50, 371-380.
Evtushenko, L. I., Dorofeeva, L. V., Krausova, V. I., Gavrish, E. Yu., Yashina, S. G. \& Takeuchi, M. (2002). Okibacterium fritillariae gen. nov., sp. nov., a novel genus of the family Microbacteriaceae. Int J Syst Evol Microbiol 52, 987-993.

Gledhill, W. E. \& Casida, L. E., Jr (1969). Predominant catalasenegative soil bacteria. III. Agromyces, gen. n., microorganisms intermediary to Actinomyces and Nocardia. Appl Microbiol 18, 340-349.

Li, W.-J., Zhang, L.-P., Xu, P., Cui, X.-L., Xu, L.-H., Zhang, Z., Schumann, P., Stackebrandt, E. \& Jiang, C.-L. (2003). Agromyces aurantiacus sp. nov., isolated from a Chinese primeval forest. Int J Syst Evol Microbiol 53, 303-307.

Ryu, E. (1938). On the Gram-differentiation of bacteria by the simplest method. J Jpn Soc Vet Sci 17, 31.

Sasaki, J., Chijimatsu, M. \& Suzuki, K. (1998). Taxonomic significance of 2,4-diaminobutyric acid isomers in the cell wall peptidoglycan of actinomycetes and reclassification of Clavibacter toxicus as Rathayibacter toxicus comb. nov. Int J Syst Bacteriol 48, 403-410.

Schleifer, K. H. \& Kandler, O. (1972). Peptidoglycan types of bacterial cell walls and their taxonomic implications. Bacteriol Rev 36, 407-477.

Suzuki, K., Sasaki, J., Uramoto, M., Nakase, T. \& Komagata, K. (1996). Agromyces mediolanus sp. nov., nom. rev., comb. nov, a species for "Corynebacterium mediolanum" Mamoli 1939 and for some aniline-assimilating bacteria which contain 2,4-diaminobutyric acid in the cell wall peptidoglycan. Int J Syst Bacteriol 46, 88-93.

Takeuchi, M. \& Hatano, K. (2001). Agromyces luteolus sp. nov., Agromyces rhizospherae sp. nov. and Agromyces bracchium sp. nov., from the mangrove rhizosphere. Int J Syst Evol Microbiol 51, 1529-1537.

Wayne, L. G., Brenner, D. J., Colwell, R. R. \& 9 other authors (1987). International Committee on Systematic Bacteriology. Report of the ad hoc committee on reconciliation of approaches to bacterial systematics. Int J Syst Bacteriol 37, 463-464.

Zgurskaya, H. I., Evtushenko, L. I., Akimov, V. N., Voyevoda, H. V., Dobrovolskaya, T. G., Lysak, L. V. \& Kalakoutskii, L. V. (1992). Emended description of the genus Agromyces and description of Agromyces cerinus subsp. cerinus sp. nov., subsp. nov., Agromyces cerinus subsp. nitratus sp. nov., subsp. nov., Agromyces fucosus subsp. fucosus sp. nov., subsp. nov., and Agromyces fucosus subsp. hippuratus sp. nov., subsp. nov. Int J Syst Bacteriol 42, 635-641. 